\title{
IMPLEMENTASI PEMBELAJARAN INSTAD UNTUK MENINGKATKAN HASIL BELAJAR PESERTA DIDIK KELAS XI IPA 3 DI SMA NEGERI 2 METRO
}

\author{
Ratna Multiwinarsih ${ }^{1}$ \\ Kartika Sari $^{2}$ \\ Agil Lepiyanto ${ }^{3}$ \\ ${ }^{1}$ SMA Negeri 2 Kota Metro \\ ${ }^{2,3}$ Pendidikan Biologi FKIP Universitas Muhammadiyah Metro \\ Email: kartika.ummetro@gmail.com
}

\begin{abstract}
Quality education will certainly produce educational outcomes, namely qualified graduates. Education does not only prepare intelligent human resources but also prepares human resources with character. Education at this time certainly must adjust to the various changes that exist in the 21 st century. Teachers must be able to design learning that fits the needs of the 21 st century.

This study aims to improve student learning outcomes. This research is a type of classroom action research. Stages of research that will be carried out are 1) planning, 2) implementation, 3) observations, and 4) reflection. The results of this study found that there was an increase in learning outcomes of students from cycle I to cycle II. The number of students who experienced an increase of 19 students or $59.375 \%$, students who experienced a decline in grades of 2 or $6.25 \%$ and 11 students were fixed value between cycle I and cycle I while for comparison the value of the average class also increased as much as $6.4 \%$.
\end{abstract}

Kata Kunci: INSTAD, Hasil Belajar

\section{PENDAHULUAN}

Pendidikan merupakan salah satu bidang yang menjadi dasar untuk mempersiapkan sumber daya manusia Indonesia yang mampu bersaing dengan negara-negara lain. Pendidikan yang berkualitas tentu akan menghasilkan luaran pendidikan yaitu lulusan-lulusan yang berkualitas. Pendidikan tidak hanya mempersiapkan sumber daya manusia yang cerdas, namun juga mempersiapkan sumber daya manusia yang berkarakter. Pendidikan saat ini tentu harus menyesuaikan dengan berbagai perubahan yang ada pada abad 21. Guru-guru harus mampu mendesain pembelajaran yang sesuai dengan kebutuhan abad 21. Pendidikan diharapkan dapat menghasilkan sumber daya manusia yang cerdas dan memiliki keterampilan untuk dapat bersaing di era abad 21.

Hasil observasi yang dilaksanakan di kelas XI IPA 3 SMA Negeri 2 Metro didapatkan bahwa pembelajaran sudah menggunakan berbagai model pembelajaran. Pembelajaran yang pernah dilaksanakan adalah diskusi. Hasil 
pembelajaran yang didapatkan di kelas XI IPA 1 pada gambar 1.

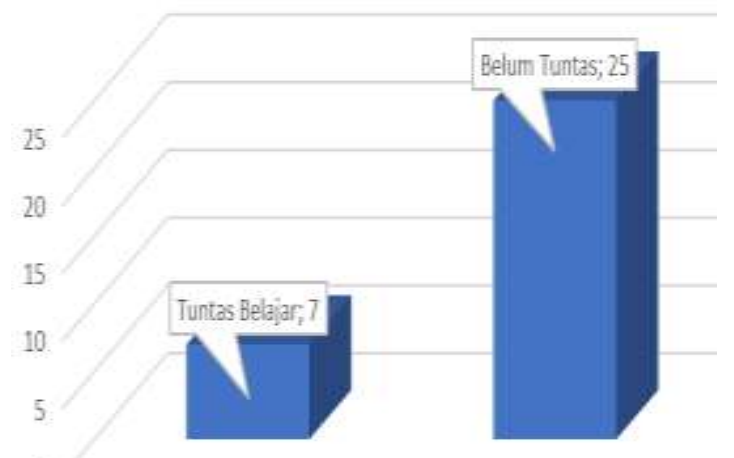

Gambar 1. Perbandingan jumlah peserta didik yang tidak lulus dan lulus KKM

Gambar 1. terlihat bahwa jumlah peserta didik yang nilainya lulus KKM hanya 7 peserta didik sedangkan yang tidak lulus sebanyak 25 peserta didik. Kondisi ini tentu harus diberikan solusi agar hasil belajar yang diperoleh peserta didik dapat meningkat. Salah satu solusi yang dapat diberikan untuk meningkatkan hasil belajar peserta didik adalah pembelajaran yang dapat memberikan pengalaman nyata kepada peserta didik. Karakteristik pembelajaran IPA menekankan pada pemberian pengalaman langsung secara inkuiri ilmiah (scientific inquiry) untuk mengembangkan kompetensi siswa. Biologi sebagai bagian dari IPA tentu tidak hanya mengembangkan konsep tetapi juga dapat memiliki andil untuk mengembangkan keterampilan lainnya (Purwadi, Akbar \& Muhardjito, 2016). Biologi bukan hanya penguasaan kumpulan pengetahuan berupa faktafakta, konsep-konsep, prinsip-prinsip saja tetapi juga merupakan suatu proses penemuan (Khasanah \& Asih, 2017).

Salah satu pembelajaran yang memberikan pengalaman nyata kepada peserta didik adalah Instad. Instad merupakan integrasi sintaks atau langkah pembelajaran inkuiri dan Stad. Inkuiri merupakan salah satu pembelajaran yang menekankan pada pola berpikir kritis, sedangkan Stad merupakan bagian pembelajaran kooperatif. Instad merupakan integrasi pembelajaran inkuri dalam pembelajaran STAD. Siswa melakukan langkah-langkah kegiatan pembelajaran secara inkuiri tetapi tidak bekerja secara individu melainkan berkolaboratif dengan teman sekelompoknya untuk mencapai tujuan bersama. Instad melatih siswa mengkonstruk pengetahuannya sendiri berdasarkan pengalaman dalam kelompoknya karena mereka dapat dengan bebas mengembangkan dan memperluas pengetahuan serta keahliannya menggunakan keterampilan yang dimiliki juga sumber informasi Ikawati, Susilo, \& Degeng (2016).

Su'udah, Degeng, \& Kuswandi (2016) menyatakan inkuiri yaitu siswa menemukan esensi pembelajaran bukan dari hasil mengingat sejumlah fakta, melainkan menemukan sendiri melalui kegiatan mengamati, menanya, mengumpulkan informasi, menalar (menemukan pola lalu menyimpulkannya), dan mengomunikasikannya.

\section{METODE}

Penelitian ini merupakan jenis penelitian tindakan kelas. Tahapan penelitian yang akan dilakukan yaitu 
1) perencanaan, 2) pelaksanaan, 3) Pengamatan, dan 4) refleksi. Penelitian dilaksanakan di SMA Negeri 2 Kota Metro dengan jumlah siswa sebanyak 33 orang.

\section{HASIL DAN PEMBAHASAN}

Hasil penelitian ini didapatkan bahwa terjadi peningkatan hasil belajar Peserta didik dari siklus I ke siklus II. Jumlah Peserta didik yang mengalami peningkatan sebanyak 19 Peserta didik atau 59,375\%, Peserta didik yang mengalami penurunan nilai sebanyak 2 atau 6,25\% dan 11 Peserta didik nilainya tetap antara siklus I dan siklus I. Perbandingan persentase jumlah Peserta didik yang mengalami peningkatan nilai, penurunan nilai dan nilai tetap dapat dilihat pada gambar 2 . Perbandingan nilai rata-rata kelas juga mengalami peningkatan sebanyak 6,4. Perbandingan rata-rata nilai kelas dapat dilihat pada gambar 3. Hasil belajar yang diperoleh oleh Peserta didik siklus I dan Siklus I yang mengalami peningkatan, hal ini mununjukkan bahwa kualitas pembelajaran yang dilaksanakan juga mengalami peningkatan dari segi kualitas. Hasil ini penelitian ni relevan dengan hasil penelitian Kurniawan (2013) metode inkuiri terbimbing dapat meningkatkan pemahan konsep siswa pada siklus I diperoleh hasil nilai ketuntasan klasikal sebesar $78,05 \%$ dan pada siklus II sebesar 97,56\%. Penelitian lain juga menunjukkan bahwa inkuiri dapat meningkatkan hasil belajar siswa. Menurut Ratnaningrum, Chamisijatin \& Widowo (2015) peningkatan hasil belajar IPA pada siswa kelas VIII-A SMP Muhammadiyah 2 Batu melalui pembelajaran guided inquiry dapat meningkat sebesar 10,46\%. Berikut data hasil belajar selama penelitian.

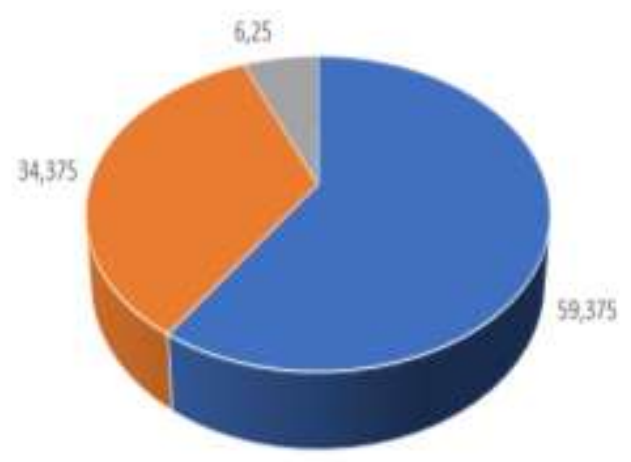

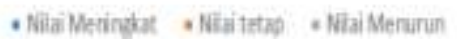

Gambar 2. Data jumlah peserta didik yang meningkat, nilai tetap dan nilai menurun.

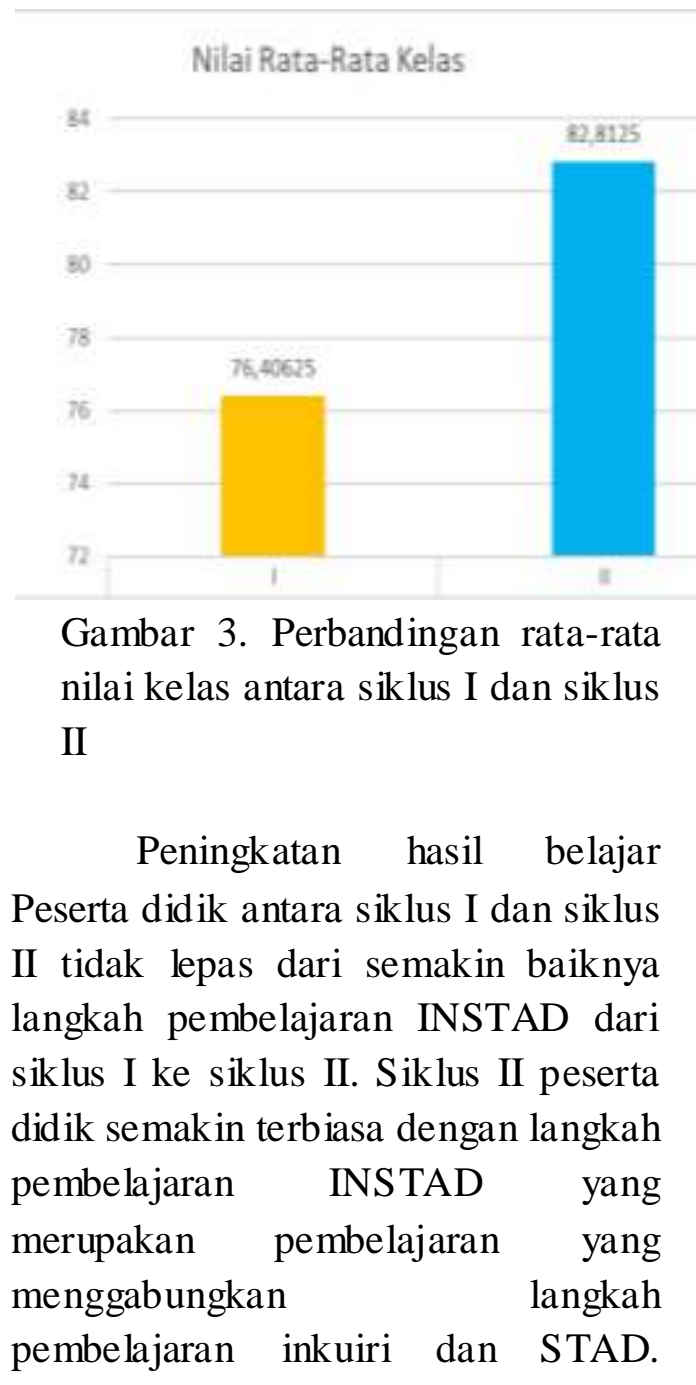


Langkah inkuiri yang dikembangkan terdiri atas merumuskan masalah, membuat hipotesis, mengumpulkan data, menganalisis dan menyimpulkan (Pratiwi \& Lepiyanto, 2017). Putra (2013) menyebutkan inkuiri merupakan suatu proses untuk memperoleh informasi melalui observasi atau eksperimen untuk memecahkan suatu masalah dengan menggunakan kemampuan berpikir kritis dan logis. Pembelajaran inkuiri akan memberikan pengalaman kepada peserta didik dalam mengamati suatu objek. Pelaksanaan pembelajaran dalam penelitian ini peserta didik melakukan berbagai pengamatan. Pengamatan melalui percobaan dan mengamati video terkait materi akan membuat peserta didik dihadapkan dalam kondisi nyata pada setiap pembelajaran. Proses pengamatan ini merupakan bagian dari siswa untuk memperoleh data yang akan dibahas untuk membuktikan hipotesis yang telah diajukan sebelumnya. Proses selanjutnya adalah siswa menganalisis data dan membahas dengan berbagai referensi untuk mendapatkan kajian yang sesuai dengan hopotesis. Proses ini akan membuat siswa berusaha untuk menggali berbagai informasi sehingga dapat menukan jawaban dari hoptesis yang telah diajukan. Siswa akan memperoleh pengalaman menemukan jawaban sendiri dan berpikir logis pada saat siswa melakukan proses investigasi informasi yang relevan terkait dengan hipotesis yang diajukan (Sutama, Arnyana, \& Swasta, 2014).

Pengalaman nyata ini akan membuat siswa lebih mudah mengingat materi yang disampaikan pada masing-masing pertemuan. Strategi pembelajaran inkuiri adalah rangkaian kegiatan pembelajaran yang menekankan pada proses berpikir secara kritis dan analitis untuk mencari dan menemukan sendiri jawaban yang sudah pasti dari suatu masalah yang dipertanyakan (Sanjaya, 2015). Menurut Putra (2013) pembelajaran inkuiri menekankan pada aktivitas belajar peserta didik untuk mencari dan menemukan informasi. Aktivitas mencari dan menemukan informasi ini peserta didik akan saling bekerjasama, saling bertanya dan saling bertukar informasi antara peserta didik yang satu dengan peserta didik yang lain. Purwati, Prayitno dan Sari, (2016) menyatakan model pembelajaran inkuiri terbimbing mampu mengakomodasi siswa menjadi lebih aktif, terampil, dan terlibat langsung dalam proses pembelajaran. Langkah pembelajaran ini diharapkan dapat memberikan pengalaman yang lebih untuk memahami konsep. Siswa antusias dalam melakukan pengamatan, karena percobaan yang dilakukan merupakan hal baru bagi siswa (Setiawati, Retnoningsih, \& Irsadi, 2017).

Siswa menemukan sendiri konsep materi pelajaran melalui bimbingan guru ditambah dengan pengalaman yang berkaitan dengan kehidupan nyata, siswa tersebut akan mendapatkan pemahaman yang lebih baik Kartika, Susilo \& Dasna (2016). Aktivitas bertanya dalam pembelajaran memiliki peranan memusatkan perhatian pada pokok masalah. Aktivitas bertanya ini juga dapat digunakan untuk mendiagnosis kesulitan belajar peserta didik. 
Adanya aktivitas bertanya ini tentu akan memunculkan aktivitas mengungkapkan pendapat dari peserta didik yang lain. Transfer pengetahuan ini juga akan membuat peserta didik lebih mudah dalam materi pembelajaran (Gulo, 2008)..

Pembelajaran STAD sebagai bagian pembelajaran kooperatif memberikan andil peningkatan hasil belajar siswa, (Susanto, 2016). Pembelajaran STAD merupakan pembelajaran yang bertujuan untuk memotivasi peserta didik untuk berani dan saling menolong dalam menguasai materi yang diajarkan oleh guru. STAD meningkatkan pemahaman siswa. secara rinci bagaimana STAD dapat meningkatkan hasil belajar siswa sebagai berikut (Fitriasari \& Juanengsih, 2015).

1. Pembelajaran STAD membuat Peserta didik memiliki rasa tanggungjawab terhadap keberhasilan kelompok. Rasa tanggungjawab terhadap kelompok muncul karena salah satu tahapan pembelajaran STAD adalah pemberian kuis. Pemberian kuis ini dilakukan untuk mengukur tingkat penguasaan materi Peserta didik pada saat pembelajaran. Guru akan melakukan penilaian secara individu, kemudian melakukan analisis skor kemajuan individu dan terakhir akan menganalisis nilai rata-rata skor kemajuan kelompok. Proses ini akan menimbulkan kompetisi antar kelompok. Masing-masing peserta didik tentu tidak ingin mendapat skor kuis yang kecil karena akan berdampak skor kemajuan kelompok juga berkurang. Hal inilah yang akan membuat Peserta didik memiliki rasa tanggungjawab terhadap keberhasilan kelompok. Berdasarkan pendapat Rusman (2011) penerapan pembelajaran kooperatif dua atau lebih individu saling tergantung satu sama lain untuk mencapai satu penghargaan bersama. Penghargaan yang diberikan pada penelitian ini berupa hadiah yang bervariasi, diantaranya adalah pulpen 1 kotak, gantungan kunci, dan buku. Penghargaan yang diberikan tidak hanya berupa benda atau produk, tetapi juga berupa pujian kepada kelompok yang memiliki prestasi untuk masing-masing pertemuan. Adanya penghargaan ini berdampak peserta didik akan semangat dalam pembelajaran.

2. Pembelajaran STAD membuat Peserta didik saling bekerjasama dalam menyelesaikan tugas Rusman (2011) menjelaskan bahwa pembelajaran kooperatif adalah pembelajaran secara tim. Setiap anggota tim harus saling membantu untuk mencapai tujuan pembelajaran. Pembelajaran secara tim atau kelompok ini akan memberikan kebiasaan kepada peserta didik untuk saling membantu dalam menyelesaikan tugas yang diberikan kepada guru. Peserta didik akan saling berinteraksi satu dengan yang lain. Peserta didik yang memiliki kemampuan lebih tinggi akan membantu Peserta didik yang yang memiliki kemampuan lebih rendah. Rusman 
menyatakan pembelajaran STAD guru memberikan waktu untuk Peserta didik bekerja dalam kelompok, dalam kerja kelompok memungkinkan Peserta didik akan saling membantu, mendiskusikan ketidaksamaan dan mendiskusikan dalam pemecahan masalah yang diberikan oleh guru. Ambarsari, Santoso, \& Maridi (2016) menyatakan melalui proses diskusi siswa akan terlatih untuk bertanya dan berusaha menjawab pertanyaan. Menurut Fitriyani, Haryani, \& Susatyo (2016) dalam diskusi siswa dapat bertukar pikiran dengan siswa lainnya sehingga kreativitas siswa dapat meningkat. Pendapat Ambarsari, Santoso, \& Maridi (2016) saat proses diskusi siswa dapat belajar untuk bertukar pikiran dengan temannya dan saling melengkapi satu sama lain. Kerja tim merupakan ciri terpenting STAD (Rusman, 2011).

3. Pembelajaran STAD membuat Peserta didik semakin termotivasi dalam pembelajaran Salah satu ciri pembelajaran kooperatif adalah adanya pengakuan tim ata penghargaan. Penghargaan tim dalam pembelajaran kooperatif dapat berupa penetapan kelompok yang paling berprestasi dan memberikan hadiah kepada kelompok yang berprestasi diharapkan dapat memotivasi Peserta didik dari setiap kelompok untuk terus berprestas $\mathrm{i}$ lagi. Motivasi yang dimiliki siswa ini muncul karena adanya video yang ditampilkan oleh guru (Rusman, 2011). Penggunaan media video dalam pembelajaran bertujuan untuk memudahkan siswa dalam memahami materi (Setiawati, Retnoningsih, \& Irsadi, 2017).

\section{KESIMPULAN}

Hasil penelitian ini didapatkan bahwa terjadi peningkatan hasil belajar Peserta didik dari siklus I ke siklus II. Jumlah Peserta didik yang mengalami peningkatan sebanyak 19 Peserta didik atau 59,375\%, Peserta didik yang mengalami penurunan nilai sebanyak 2 atau $6,25 \%$ dan 11 Peserta didik nilainya tetap antara siklus I dan siklus I sedangkan untuk perbandingan nilai rata-rata kelas juga mengalami peningkatan sebanyak $6,4 \%$

\section{DAFTAR RUJUKAN}

Ambarsari, W., Santoso, S., dan Maridi. 2016. Penerapan Pembelajaran Inkuiri Terbimbing Terhadap Keterampilan Proses Sains Dasar Pada Pelajaran Biologi Siswa Kelas VIII SMP Negeri 7 Surakarta Jurnal Pendidikan Biologi Volume 5, Nomor 1 Januari 2013 Halaman 81-95

Fitriyani, R., Haryani, S. \& Susatyo, E. B. 2016. Pengaruh Model Inkuiri Terbimbing Terhadap Keterampilan Proses Sains Pada Materi Kelarutan Dan Hasil Kali Kelarutan Jurnal Inovasi Pendidikan Kimia, Vol. 11, No. 2, 2017, hal: 1957-1970

Fitriasari dan Juanengsih, N. 2015. Upaya Peningkatan Hasil Belajar Biologi Pada Konsep Daur Biogekimia Melalui Pembelajaran Kooperatif Tipe 
STAD Pada Siswa Kelas $\mathrm{X}$ Semester II Tahun Ajaran 2014/2015. Prosiding Seminar Nasional Biologi, Lingkungan, dan Pembelajaran. Pendidikan Biologi FITK Syarif Hidayatullah Jakarta.

Gulo. W. 2008. Strategi Belajar Mengajar. Grasindo: Jakarta

Ikawati, Susilo, H., dan Degeng, I.N.S. 2016. Pemberdayaan Keterampilan Ilmiah Pada Pembelajaran Ipa Melalui Strategi Inkuiri Terbimbing Dipadu Stad (Student Team Achievement Division).

Prosiding Seminar Nasional Pendidikan Dasar 2016"Peningkatan Kualitas Pendidikan Dasar dalam Menghadapi Daya Saing Regional (ASEAN). Program Studi Pendidikan Dasar Pascasarjana Universitas Negeri Malang

Kartika, S.N., Susilo, H., \& Dasna, I.

W. 2016. Peningkatkan Motivasi Belajar IPA Siswa SD Melalui Penerapan Model Pembelajaran Inkuiri Terbimbing Berbantuan Mind Map. Prosiding Seminar Nasional Pendidikan Dasar 2016"Peningkatan Kualitas Pendidikan Dasar dalam Menghadapi Daya Saing Regional (ASEAN). Program Studi Pendidikan Dasar Pascasarjana Universitas Negeri Malang.

Khasanah, D. \& Asih, T. 2017. Pengembangan modul berbasis guided discovery pada Materi protista untuk pembelajaran biologi siswa SMA Kelas $\mathrm{x}$.
Prosiding Seminar Nasional Pendidikan. FKIP.Universitas Muhammadiyah Metro.

Kurniawan, A.D. 2013. Metode Inkuiri Terbimbing Dalam Pembuatan Media Pembelajaran Biologi Untuk Meningkatkan Pemahaman Konsep Dan Kreativitas Siswa Smp. JPII 2 (1) (2013) 8-11 Jurnal Pendidikan IPA Indonesia

Purwadi, Akbar, S., \& Muhardjito. 2016. Strategi Pembelajaran Guided Inquiry Melalui Practice Rehearsal Pairs Pada Pembelajaran IPA Kelas IV

Sekolah Dasar. Prosiding Seminar Nasional Pendidikan Dasar 2016"Peningkatan Kualitas Pendidikan Dasar dalam Menghadapi Daya Saing Regional (ASEAN)". Program Studi Pendidikan Dasar Pascasarjana Universitas Negeri Malang

Purwati, R., Prayitno, B.A., \& Sari, D.

P. 2016. Penerapan Model Pembelajaran Inkuiri Terbimbing Pada Materi Sistem Ekskresi Kulit Untuk Meningkatkan Keterampilan Proses Sains Siswa Kelas XI SMA Proceeding Biology Education Conference Seminar Nasional XIII Pendidikan Biologi FKIP UNS, Vol 13 (1) 2016: 325-329

Pratiwi, D. \& Lepiyanto, A. 2017. Profil Pembelajaran Berbasis Inkuiri Terintegrasi Nilai Karakter Pada Matakuliah Morfologi Tumbuhan. Prosiding Seminar Nasional Pendidikan. 
FKIP.

Universitas

Muhammadiyah Metro.

Putra, S. R. 2013. Desain belajar mengajar kreatif berbasis sains.

Diva Press: Jogjakarta

Ratnaningrum, D. A., Chamisijatin, L. \& Widowo, N. 2015. Penerapan Pembelajaran Guided Inquiry Untuk Meningkatkan Motivasi Dan Hasil Belajar Ipa Pada Siswa Kelas VIII- A SMP Muhammadiyah 2 Batu. Jurnal Pendidikan Biologi Indonesia Volume 2 Nomor 1, Hal 230239.

Rusman. 2011. Model-Model

Pembelajaran Mengembangkan

Profesionalisme

Guru.

Rajagrafindo: Jakarta.

Sanjaya, W. 2015. Kurikulum Dan

Pembelajaran (Teori \& Praktek KTSP). Kencana Prenadamedia Group: Jakarta.

Setiawati, M., Retnoningsih, A. \& Irsadi, A. (2017) Efektifitas Praktikum Berbasis Guided Inquiry Diintegrasikan Dengan Video Transfer Membran Terhadap Keterampilan Proses Sains (Kps) dan Pemahaman Konsep Siswa. J. Biol. Educ. Journal of Biology Education. 6 (1).

Susanto, A. 2016. Pengembangan pembelajaran IPS di Sekolah Dasar. Kencana: Jakarta.

Sutama, I. N., Arnyana, I. B. P., \& Swasta, I.B.J. 2014. Pengaruh Model Pembelajaran Inkuiri Terhadap Ketrampilan Berpikir Kritis Dan Kinerja Ilmiah Pada Pelajaran Biologi Kelas Xi IPA SMA Negeri 2 Amlapura. $e$ Journal Program Pascasarjana
Universitas Pendidikan Ganesha Program Studi IPA. Volume 4.

Su'udah, F., Degeng, I.N.S \& Kuswandi, D. 2016. Pembelajaran Kontekstual Dan Pendekatan Saintifik Di Sekolah Dasar. Prosiding Seminar Nasional Pendidikan Dasar 2016"Peningkatan Kualitas Pendidikan Dasar dalam Menghadapi Daya Saing Regional (ASEAN)". Program Studi Pendidikan Dasar Pascasarjana Universitas Negeri Malang. 